\title{
Isolation and Growth of a Pseudomonas Species that Utilizes Cyanide as a Source of Nitrogen
}

\author{
By RALPH HARRIS AND CHRISTOPHER J. KNOWLES* \\ Biological Laboratory, University of Kent, Canterbury, Kent CT2 7NJ, U.K.
}

(Received 12 July 1982; revised 23 November 1982)

\begin{abstract}
A simple method of isolating bacteria that utilize cyanide as a source of nitrogen for growth has been developed. This involved supplying hydrogen cyanide as a vapour to glucose-containing minimal-salts agar plates. The bacteria isolated were Gram-negative, oxidase-positive rods producing a fluorescent green pigment and were tentatively identified as strains of Pseudomonas fluorescens. Three organisms were studied further and shown to be $P$. fluorescens biotype II. One of these (NCIB 11764) was grown in a glucose-containing fed-batch culture with either $\mathrm{NH}_{4} \mathrm{Cl}$ or $\mathrm{KCN}$ as the limiting nutrient. Cyanide-grown bacteria produced stoichiometric amounts of ammonia from cyanide when pulsed with cyanide under aerobic conditions. Stimulation of oxygen uptake was seen on addition of cyanide to suspensions of cyanide-grown but not ammonia-grown bacteria.
\end{abstract}

\section{INTRODUCTION}

Considerable amounts of cyanide are found in the environment, due to both natural synthesis and industrial production (Knowles, 1976). Pettet \& Ware (1955) and Ware \& Painter (1955) reported the isolation of cyanide-utilizing bacteria. Colonies developed on silica gel with cyanide as the sole source of carbon and nitrogen. The colonies were mixed cultures of a Gramnegative bacillus and a Gram-positive filamentous organism which was probably an actinomycete. Unfortunately the bacteria have not been retained ( $\mathrm{Dr} \mathrm{H}$. A. Painter, personal communication). Winter (1963) extended the studies of Pettet \& Ware (1955) and isolated two organisms from acclimated sludge seeded on to coke-filled percolating filters. They were faculative autotrophs and probably actinomycetes. Cultures of these bacteria were kindly provided by Dr J. A. Winter but appear to have lost the capacity to utilize cyanide (P. A. Collins \& C. J. Knowles, unpublished observations). There have been several other publications which suggest that bacteria might be able to grow on cyanide (see Knowles, 1976).

The toxicity of cyanide presents problems in isolating bacteria capable of using it as a substrate for growth. Thus a high enough concentration of cyanide to support appreciable growth might prove to be too toxic to allow growth to occur. Since the amount of nitrogen needed for a given amount of growth is less than the requirement for carbon, it might be easier to isolate bacteria that utilize cyanide as a nitrogen source in the presence of a separate source of carbon and energy. Possible approaches to isolating cyanide-utilizing bacteria include (a) enrichment in continuous culture with cyanide as the limiting nutrient, and (b) enrichment on solid media on plates exposed to a low, continuous supply or repeated small doses of hydrogen cyanide. Preliminary experiments using the former method have been unsuccessful (N. Nazly \& C. J. Knowles, unpublished observations). In this paper we report a simple method for isolation of bacteria that utilize cyanide as a nitrogen source using the latter approach, and the growth of one of them in liquid batch culture. 


\section{METHODS}

Growth medium. A minimal salts medium was used for isolation of bacteria and the subsequent growth of Pseudomonas fluorescens. This consisted of M-9 salts (Miller, 1972) with ammonium salts omitted and $1 \mathrm{ml}$ trace metals $1^{-1}$ (Bauchop \& Elsden, 1960). Where required the medium was solidified with $1 \cdot 5 \%$ (w/v) Oxoid purified agar. Glucose (10 mM) was routinely used as the carbon source. On plates the nitrogen source was either $10 \mathrm{~mm}$ $\mathrm{NH}_{4} \mathrm{Cl}$ incorporated into the agar or $\mathrm{KCN}$ supplied by the method given below. In liquid starter cultures $1.5 \mathrm{~mm}-$ $\mathrm{NH}_{4} \mathrm{Cl}$ was added as the nitrogen source. In fed-batch cultures the limiting nutrient was the nitrogen source which was either $\mathrm{KCN}$ or $\mathrm{NH}_{4} \mathrm{Cl}$ (see below).

Isolation of cyanide-utilizing bacteria. Samples of mud, soil and activated sludge were diluted 20- to 8000 -fold with water and $0.1 \mathrm{ml}$ portions spread on to a glucose-containing plate free of combined nitrogen. Cyanide, as a nitrogen source, was supplied as $\mathrm{HCN}$, originating from a KCN solution. Plates were inverted and a square (about $\left.25 \mathrm{~mm}^{2}\right)$ of sterile Whatman grade $3 \mathrm{MM}$ filter paper placed in the lid. Filter-sterilized $\mathrm{KCN}$ solution $(0 \cdot 2 \mathrm{ml}$, $20 \mathrm{mM}$ ) was applied to the filter paper. The filter papers were replaced daily and freshly prepared $\mathrm{KCN}$ solution was added to the replacement filters. Plates were incubated at room temperature in the dark in a fume cupboard. Individual colonies appearing after 3-15 d exposure to cyanide were streaked on to plates containing glucose and $\mathrm{NH}_{4} \mathrm{Cl}$. Single colonies were re-streaked on to glucose $/ \mathrm{NH}_{4} \mathrm{Cl}$ plates, and the process repeated twice more to obtain pure strains. The ability of purified isolates to utilize cyanide as a nitrogen source was checked on plates provided with hydrogen cyanide as indicated above and comparing with growth on control plates which had no combined nitrogen.

Organism. A $P$. fluorescens strain isolated by the method given above was maintained on nutrient agar slants $\left(2.5 \% \mathrm{w} / \mathrm{v}\right.$, Oxoid) at $4{ }^{\circ} \mathrm{C}$, and subcultured at intervals of about 6 weeks.

Taxonomic tests were kindly carried out by Dr J. V. Lee (Public Health Laboratory Service, Preston Hall Hospital, Maidstone, Kent, U.K.) and Mrs A. J. Baxter (National Collection of Industrial Bacteria, Torry Research Station, Aberdeen, U.K.), and were based on the methods given in Cowan (1974).

Fed-batch culture of $P$. fluorescens. A 1 litre Pyrex Quickfit culture vessel containing $500 \mathrm{ml}$ medium was maintained at $30^{\circ} \mathrm{C}$ by means of a water jacket, magnetically stirred, and sparged with filter-sterilized air at $500 \mathrm{ml} \mathrm{min}{ }^{-1}$. Glucose $(10 \mathrm{~mm})$ was used as the carbon source and $\mathrm{KCN}$ or $\mathrm{NH}_{4} \mathrm{Cl}$ as the nitrogen source, supplied at an exponentially increasing rate using the exponential feeding device described below. Inocula were prepared by washing a nutrient agar slant into $100 \mathrm{ml}$ medium containing $10 \mathrm{~mm}$-glucose and $1.5 \mathrm{~mm}-\mathrm{NH}_{4} \mathrm{Cl}$ in a $250 \mathrm{ml}$ conical flask. This culture was grown for $48 \mathrm{~h}$ at $30^{\circ} \mathrm{C}$ on a rotary shaker (250 r.p.m.), after which both the glucose and the $\mathrm{NH}_{4}{ }^{+}$were depleted from the medium and the culture had an $A_{600}$ of about 1.5 . A $5 \%$ (v/v) sample (25 ml) was used to inoculate the culture vessel.

Exponential feeding device. In order to supply a nitrogen source as the growth-limiting substrate at an exponentially increasing rate, a gradient-generating device was adapted to sterile operation. The theory of exponential gradient generators has been described in detail (Solano-Muñoz \& Bardsley, 1981; Peterson, 1970). The device used in this study was constructed from three $40 \mathrm{ml}$ test tubes with side arms at the bottom of the tubes connected in series via flexible tubing containing $1 \mathrm{~mm}$ constrictions. Bacteriological filters were fitted to the tops of each of the test tubes. After sterilization of the complete apparatus, sterile solutions of the nitrogen source were injected into the gradient generator via Suba-Seal stoppers (Astell Laboratory Service Co., Catford, London, U.K.). The test tube distal to the culture vessel contained $20 \mathrm{ml}$ of $200 \mathrm{~mm}-\mathrm{NH}_{4} \mathrm{Cl}$ or $\mathrm{KCN}$ in water. The other two

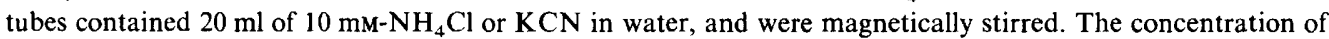
solute in the outflow from the gradient generator increased exponentially with a linear increase in the volume delivered. Solute was pumped via a peristaltic pump into the culture vessel at the rate of about $2 \cdot 1 \mathrm{ml} \mathrm{h}^{-1}$. In order to prevent back-contamination of the nitrogen feed, the inlet into the culture from the gradient generator was via a medium 'break' (Drew, 1981) in the air-entry tube.

$\mathrm{O}_{2}$ uptake measurements. $\mathrm{O}_{2}$ uptake was determined with an $\mathrm{O}_{2}$ electrode (Rank Bros., Bottisham, Cambridge, U.K.). Bacteria were harvested in the mid-exponential phase by centrifugation at $30000 \mathrm{~g}$ for $10 \mathrm{~min}$ at $4{ }^{\circ} \mathrm{C}$, washed twice in $\mathrm{Na}_{2} \mathrm{HPO}_{4} / \mathrm{NaH}_{2} \mathrm{PO}_{4}$ buffer $(50 \mathrm{mM}, \mathrm{pH} 7.0$ or 7.6) and resuspended in fresh buffer such that a 200 -fold dilution had an $A_{600}$ of about $1 \cdot 0$. Respiration was measured at $30^{\circ} \mathrm{C}$. The incubation mixture contained $4 \mathrm{ml}$ buffer and oxygen uptake was initiated by addition of $20 \mu \mathrm{l}$ bacteria followed, after the desired interval, by $10-20 \mu \mathrm{KCN}$ to the concentration indicated

Determination of the effect of $\mathrm{O}_{2}$ depletion on cyanide conversion to ammonia. A $10 \mathrm{ml}$ plastic syringe containing $10 \mathrm{ml}$ of air-saturated buffer $\left(50 \mathrm{mM}-\mathrm{Na}_{2} \mathrm{HPO}_{4} / \mathrm{NaH}_{2} \mathrm{PO}_{4}, \mathrm{pH} 7.0\right)$ was used as a reaction vessel. Harvested, washed bacteria $\left(A_{600}=1.0\right)$ and $\mathrm{KCN}$ substrate $(500 \mu \mathrm{M})$ were injected into the syringe via the nozzle and mixed via magnetic stirring. Samples were taken for cyanide and ammonia determination by depressing the plunger, which avoided introduction of air into the reaction mixture. A similar process was carried out in parallel in an $\mathrm{O}_{2}$ electrode chamber to determine the time at which $\mathrm{O}_{2}$ became depleted.

Analytical methods. Growth in liquid culture was estimated from the $A_{600}$ using $10 \mathrm{~mm}$ cuvettes. The Beer-

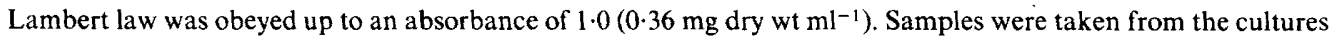


by a syringe through a Suba-Seal in the lid of the culture vessel. Bacteria were removed by centrifugation for $1 \mathrm{~min}$ in a Microfuge centrifuge (Beckman Instruments, Palo Alto, Calif., U.S.A.) and the ammonia and cyanide content of the medium determined colorimetrically by the methods of Fawcett \& Scott (1960) and Lambert et al., (1975), respectively. Ammonia was also assayed specifically using glutamate dehydrogenase, EC 1.4.1.3 (Kun \& Kearney, 1974).

\section{RESULTS}

We attempted to use the procedure described in Methods to isolate bacteria from several habitats, including soils, activated sludge and river muds. Cyanide-utilizing bacteria were successfully and repeatedly isolated from samples taken at one site only. This was from river mud samples taken from the bank of Billingham Beck at the point where it enters the River Tees (Ordnance Survey map 93, grid reference 478200).

Using these samples as inocula, no colonies appeared on media that did not contain glucose or $\mathrm{NH}_{4} \mathrm{Cl}$ when exposed to cyanide vapour, i.e. we did not detect any bacteria that were able to utilize cyanide as a carbon source. Very few colonies were found on plates containing only glucose, suggesting that few aerobic nitrogen-fixing bacteria were present in the mud samples. Plates that contained agar with glucose but no added $\mathrm{NH}_{4} \mathrm{Cl}$ developed large colonies when exposed to the vapour from a filter paper moistened with $0.2 \mathrm{ml} 20 \mathrm{mM}-\mathrm{KCN}$ which was changed daily. Hydrogen cyanide is volatile (b.p. $=26^{\circ} \mathrm{C}$; Appleby, 1969), and the cyanide vapour from the filter paper could be used as a nitrogen source at this low concentration to give visible growth if its presence was maintained. Higher concentrations of $K C N$ applied to the filter paper prevented growth, probably due to an increase in hydrogen cyanide concentration in the vapour phase and hence a greater concentration of cyanide dissolved in the growth medium. When both glucose and $\mathrm{NH}_{4} \mathrm{Cl}$ were present in the medium, increasing concentrations of cyanide in the vapour phase caused a decrease in the number of bacterial colonies formed, due to inhibition of growth of cyanide-sensitive bacteria.

All of the isolates purified from the plates with glucose as the carbon source and cyanide as the nitrogen source were Gram-negative, oxidase-positive rods producing a green pigment when grown on medium B of King et al. (1954). The pigment was fluorescent under UV light. They were tentatively identified as Pseudomonas fluorescens. Three strains were selected for further taxonomic tests. They were identified as strains of $P$. fluorescens biotype II. One of the organisms, which did not clump in liquid culture, was selected for further study. A culture of this bacterium has been deposited with the National Collection of Industrial Bacteria (NCIB 11764) and has been confirmed as $P$. fluorescens biotype II. The characteristics of this organism were: growth at $4{ }^{\circ} \mathrm{C}$ and $37{ }^{\circ} \mathrm{C}$ but not at $41{ }^{\circ} \mathrm{C}$; reduction of nitrate to dinitrogen; growth on arabinose, arginine, citrate, ethanol, glucose, lactate, propionate, trehalose and valine, but not inositol; no hydrolysis of arginine, aesculin, casein, gelatin, starch and Tween 80; urease positive but lecithinase, lipase and DNAase negative; no levan production from sucrose. The strain was atypical for lack of gelatin hydrolysis and levan production.

The bacterium was grown in fed-batch culture with the nitrogen source $\left(\mathrm{NH}_{4} \mathrm{Cl}\right.$ or $\left.\mathrm{KCN}\right)$ as the limiting nutrient (Fig. 1). This was to prevent exposure of the bacteria to cyanide at levels toxic to growth. Under the conditions used the concentration of the nitrogen source in the medium was very low $\left(\mathrm{NH}_{4}{ }^{+} \leqslant 20 \mu \mathrm{M} ; \mathrm{CN}^{-}\right.$undetectable). Growth terminated due to depletion of glucose from the medium, when the culture had an $A_{600}$ of about $1.6(0.58 \mathrm{mg}$ dry wt $\mathrm{ml}^{-1}$ ) irrespective of whether ammonia or cyanide had been supplied as the nitrogen source. Once growth had terminated, the nitrogen source supplied $\left(\mathrm{NH}_{4}{ }^{+}\right.$or $\left.\mathrm{CN}^{-}\right)$began to build up in the medium. In the case of cyanide-fed cultures the appearance of cyanide in the medium was accompanied by the appearance of ammonia (see below). The nitrogen source was supplied at a rate such that the generation time was about $5 \mathrm{~h}$. The shape of the gradient produced by the apparatus, together with the slight dilution effect, produced a growth curve which was slightly eonvex on a semi-logarithmic graph (Fig. 1). Attempts to grow the bacterium at a higher rate with cyanide as the nitrogen source, by increasing the concentration of cyanide in the gradient reservoirs or the rate at which the gradient was pumped into the culture, were unsuccessful; cyanide accumulated in the medium and prevented growth. Higher growth rates could be 


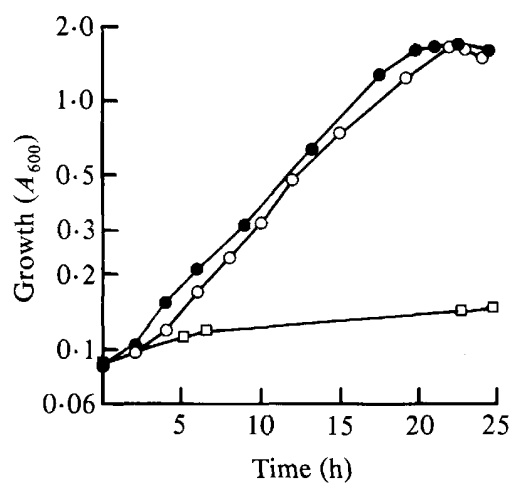

Fig. 1. Growth of $P$. fluorescens in fed-batch culture with $\mathrm{KCN}(\mathrm{O})$ or $\mathrm{NH}_{4} \mathrm{Cl}(O)$ as the nitrogen source, or with no source of combined nitrogen supplied ( $\square$ ).
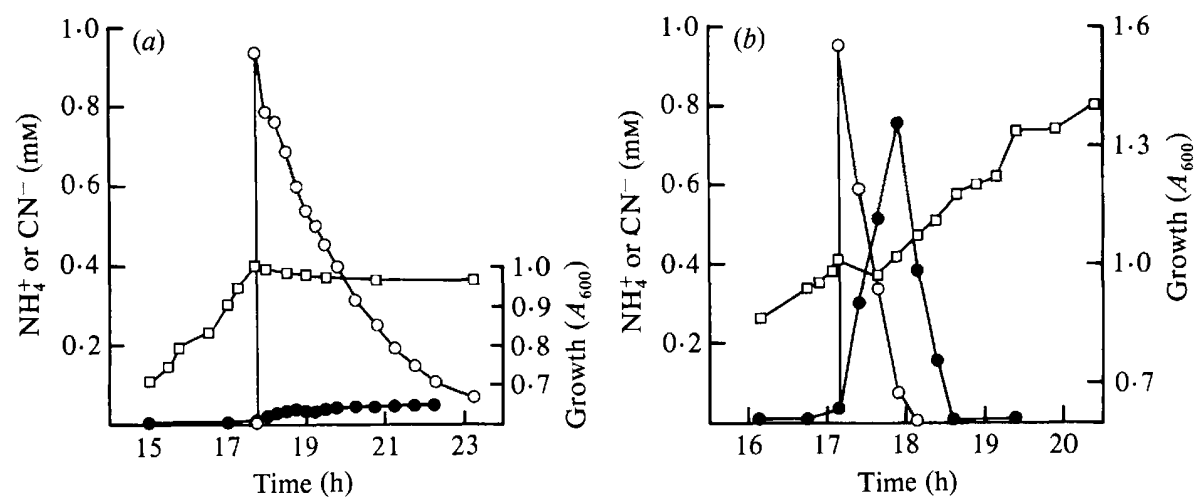

Fig. 2. Effect of pulsing (a) an $\mathrm{NH}_{4} \mathrm{Cl}$-grown culture and $(b)$ a $\mathrm{KCN}$-grown culture with $\mathrm{KCN}$ (1 mM) when their $\boldsymbol{A}_{600}$ was 1.0 . At the time of $\mathrm{KCN}$ addition the nutrient feed was terminated but sparging with air continued. Samples $(2 \mathrm{ml})$ were removed at $15 \mathrm{~min}$ intervals and the culture absorbance $(\square)$, and medium ammonia $(O)$ and cyanide $(O)$ content determined.

attained with $\mathrm{NH}_{4} \mathrm{Cl}$ as the nitrogen source, up to a mean generation time of $2 \mathrm{~h}$, which was similar to that found in batch cultures in which excess $\mathrm{NH}_{4} \mathrm{Cl}(10 \mathrm{mM})$ was provided at the time of inoculation. No significant growth was seen in cultures lacking a source of combined nitrogen. This indicates that the isolate was not a cyanide-resistant nitrogen-fixing organism.

Pulsing cyanide ( $1 \mathrm{mM}$ ) into ammonia-grown cultures inhibited growth, and slightly increased the $\mathrm{NH}_{4}{ }^{+}$content of the medium (Fig. $2 a$ ). The cyanide was lost in an exponential manner (with a half time of 75 to $90 \mathrm{~min}$ ). This was due to stripping of cyanide from the medium by the air being sparged through the culture. A similar rate of loss of cyanide was observed using cyanidepulsed uninoculated, sterile medium.

In contrast, cyanide-grown cultures when pulsed with $1 \mathrm{mM}-\mathrm{KCN}$ degraded it to ammonia (Fig. $2 b$ ), with no cyanide detectable in the medium $60 \mathrm{~min}$ after the pulse. When all the cyanide had been degraded, growth (which had been arrested by the cyanide pulse) recommenced and the ammonia was assimilated by the bacteria until it was not detectable in the medium. It therefore appears that cyanide was converted, by an inducible system, to ammonia prior to assimilation.

In order to determine accurately the ratio of cyanide degraded to ammonia produced by cyanide-grown bacteria, the experiment was repeated with the air supply turned off to prevent blow-off of cyanide, although the culture was stirred to maintain a low level of aeration. When 


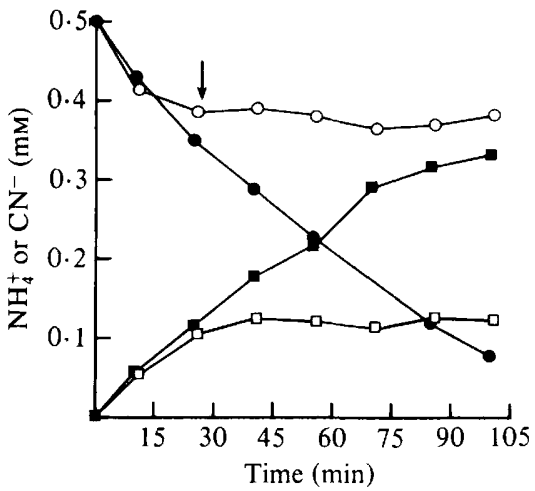

Fig. 3

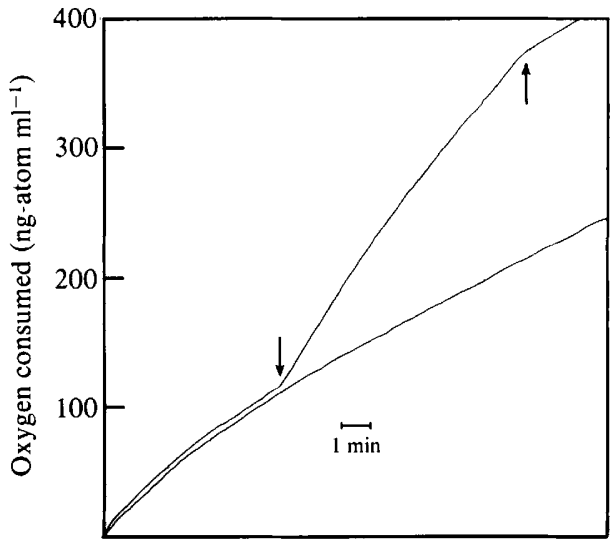

Fig. 4

Fig. 3. Cessation of cyanide conversion to ammonia on depletion of oxygen. The incubation at room temperature $\left(18 \pm 1{ }^{\circ} \mathrm{C}\right)$ was carried out as indicated in Methods. Cyanide $(O)$ and ammonia $(\square)$ in the reaction mixture in which oxygen became depleted (the time at which oxygen became depleted is indicated by the arrow). Cyanide $(\boldsymbol{O})$ and ammonia $(\square)$ in an open system in which the supply of oxygen was not limiting.

Fig. 4. Cyanide-stimulated oxygen uptake by harvested cyanide-grown bacteria. Bacteria were washed and resuspended in $50 \mathrm{~mm}-\mathrm{Na}_{2} \mathrm{HPO}_{4} / \mathrm{NaH}_{2} \mathrm{PO}_{4}$ buffer (pH 7.0), and a $20 \mu \mathrm{l}$ sample injected into an oxygen electrode chamber containing $4 \mathrm{ml}$ of the same buffer at $30^{\circ} \mathrm{C}$. The $A_{600}$ of the diluted suspension was $1 \cdot 0$. The lower line shows the endogenous rate of oxygen uptake with no additions. The upper line is the trace obtained when $20 \mu \mathrm{l}$ of $16 \mathrm{mM}-\mathrm{KCN}$ was injected at the time indicated by the first arrow (to give $80 \mu \mathrm{M}-\mathrm{KCN}$ in the suspension). The second arrow indicates the point at which cyanide was depleted from the suspension.

$1.1 \mathrm{~mm}-\mathrm{KCN}$ was added, $1.05 \mathrm{~mm}$-ammonia was formed in $220 \mathrm{~min}$ by a culture that had an $A_{600}$ of $1 \cdot 0$, implying a $1: 1$ conversion of cyanide to ammonia. Once a low medium cyanide concentration had been attained $(<50 \mu \mathrm{M})$, ammonia started to disappear from the medium, presumably due to assimilation by the bacteria. Ammonia release from cell suspensions in the absence of cyanide was negligible and cyanide was stable under the experimental conditions in the absence of bacteria. The rate of conversion of cyanide to ammonia was lower than in sparged cultures, which suggested that the rate of conversion might be controlled by the rate of aeration. That aeration was required was confirmed by using suspensions of harvested bacteria in $50 \mathrm{~mm}$ $\mathrm{Na}_{2} \mathrm{HPO}_{4} / \mathrm{NaH}_{2} \mathrm{PO}_{4}$ buffer ( $\mathrm{pH} 7 \cdot 0$ ). When these were incubated under aerobic conditions in a closed system with an adequate supply of air there was a stoichiometric release of ammonia from cyanide. In contrast, when the suspension became anaerobic in a closed chamber due to endogenous and cyanide-stimulated $\mathrm{O}_{2}$ uptake there was no further release of ammonia from the cyanide after anaerobiosis had been attained (Fig. 3). [In the open system used to demonstrate that $\mathrm{O}_{2}$ was a limiting factor in the experiment shown in Fig. 3 some cyanide was lost to the air, accounting for the stoichiometry of less than one ammonia released per unit of cyanide added.]

Harvested cyanide-grown bacteria suspended in $50 \mathrm{~mm}-\mathrm{Na}_{2} \mathrm{HPO}_{4} / \mathrm{NaH}_{2} \mathrm{PO}_{4}(\mathrm{pH} 7.0$ or 7.6) had an appreciable rate of endogenous respiration. Addition of cyanide resulted in about a doubling of the rate of oxygen uptake (Fig. 4). Oxygen uptake in the presence of cyanide, corrected for the endogenous rate of respiration, was 30 to $55 \mathrm{ng}$-atom oxygen $\mathrm{min}^{-1}$ (mg dry wt $)^{-1}$. The extra amount of oxygen utilized was proportional to the amount of $\mathrm{KCN}$ added; $1.99 \pm$ S.D. 0.16 g-atom of oxygen were taken up for each mole of $\mathrm{KCN}$ added (14 determinations with four separate batches of bacteria). Concentrations of cyanide in excess of about $1 \mathrm{~mm}$ were inhibitory and led to a decline in the rate of respiration. There was no stimulation of oxygen uptake by cyanide with suspensions of ammonia-grown bacteria. 


\section{DISCUSSION}

We have shown that bacteria able to utilize cyanide as a source of nitrogen for growth can be readily isolated from a specific environment by maintaining a sub-inhibitory concentration of cyanide for several days in enrichments. Too high a concentration of cyanide was toxic and prevented the development of these cyanide-utilizing bacteria. Similarly, growth of pure cultures of bacteria in liquid culture was inhibited if cyanide built up to a detectable level in the medium. This occurred if cyanide was provided at a rate faster than that at which it could be broken down.

The simple device used to grow the strain of $P$. fluorescens biotype II in cyanide-limited fedbatch culture during this investigation could also be used for laboratory-scale growth of organisms using other toxic substrates. Most fed-batch systems require an exponential increase in the rate of addition of the medium to achieve exponential growth, and consequently cause an exponential increase in the culture volume. The device used here results in only a small increase in culture volume, minimizing changes in the effectiveness of aeration and agitation. It does not require complex control and allows reasonable quantities of bacteria to be easily and rapidly obtained for further studies. Cyanide-limited continuous culture is preferable for more critical studies of the growth physiology of $P$. fluorescens.

The cyanide nitrogen was converted to ammonia, which is readily assimilated by pseudomonads (Brown et al., 1973). A stoichiometric conversion of cyanide to ammonia was carried out by cyanide-grown bacteria. Replacing $\mathrm{KCN}$ in the feed by $\mathrm{NH}_{4} \mathrm{Cl}$ with the same concentration gradient gave a similar amount of growth and the same doubling time.

At least one enzyme involved in the release of ammonia from cyanide must be inducible since ammonia-grown bacteria did not release ammonia from cyanide and did not exhibit any stimulation of oxygen uptake on addition of cyanide.

At this stage the steps involved in ammonia formation from cyanide are unknown but several potential routes can be envisaged (Knowles 1976; Castric, 1981). The ability of cyanide to stimulate respiration suggests that at least one step is oxidative.

We wish to thank Dr A. Beardsmore and Dr K. Powell (ICI, Billingham) for helpful discussions and encouragement, Dr J. Fletcher (ICI, Billingham) for providing mud samples, and Dr J. V. Lee (Public Health Laboratory Service, Maidstone) and Mrs A. J. Baxter (NCIB, Torry Research Station, Aberdeen) for carrying out the taxonomic tests. This work was supported by the Science and Engineering Research Council and Imperial Chemical Industries Agricultural and Mond Divisions via a C.A.S.E. studentship to R.H.

\section{REFERENCES}

APPleBY, C. A. (1969). Inhibitors of respiratory enzymes, photosynthesis and phosphorylation; uncoupling reagents. In Data for Biochemical Research, 2nd edn, pp. 380-387. Edited by R. M. C. Dawson, D. C. Elliott, W. H. Elliott \& K. M. Jones. Oxford: Clarendon Press.

Bauchop, T. \& ElsDen, S. R. (1960). The growth of micro-organisms in relation to their energy supply. Journal of General Microbiology 23, 457-469.

Brown, C. M., MacDonald-Brown, D. S. \& Stanley, S. O. (1973). The mechanisms of nitrogen assimilation in pseudomonads. Antonie van Leeuwenhoek 39, 89-98.

CASTRIC, P. A. (1981). The metabolism of hydrogen cyanide by bacteria. In Cyanide in Biology, pp. 233261. Edited by B. Vennesland, E. E. Conn, C. J. Knowles, J. Westley \& F. Wissing. London and New York: Academic Press.

Cowan, S. T. (1974). Cowan and Steel's Manual for the Identification of Medical Bacteria, 2nd edn. Cambridge: Cambridge University Press.

Drew, S. W. (1981). Liquid culture. In Manual of Methods for General Bacteriology, pp. 151-178.
Edited by P. Gerhardt, R. G. E. Murray, R. N. Costilow, E. W. Nester, W. A. Wood, N. R. Krieg, \& G. B. Phillips. Washington, D.C.: American Society for Microbiology.

FAwCETT, J. K. \& ScotT, J. E. (1960). A rapid and precise method for the determination of urea. Journal of Clinical Pathology 13, 156-160.

KING, E. O., Ward, M. K. \& Raney, D. E. (1954). Two simple media for the demonstration of pyocyanin and fluorescin. Journal of Laboratory and Clinical Medicine 44, 301-307.

KNOWLES, C. J. (1976). Microorganisms and cyanide. Bacteriological Reviews 40, 652-680.

Kun, E. \& KEARNEY, E. B. (1974). Enzymatic determination of ammonia. In Methods of Enzymatic Analysis, 2nd English edn, vol. 4, pp. 1802-1806. Edited by H. U. Bergmeyer. New York and London: Academic Press.

Lambert, J. L., Ramasamy, J. \& Paukstelis, J. V. (1975). Stable reagents for the colorimetric determination of cyanide by modified König reactions. Analytical Chemistry 47, 916-918.

MILlER, J. H. (1972). Experiments in Molecular 
Genetics, p. 431. Cold Spring Harbor, New York: Cold Spring Harbor Laboratory.

Peterson, E. A. (1970). Cellulosic ion exchangers. In Laboratory Techniques in Biochemistry and Molecular Biology, vol. 2, part II, pp. 327-354. Edited by T. S. Work \& E. Work. Amsterdam: North Holland/Elsevier.

Pettet, A. E. J. \& Ware, G. C. (1955). Disposal of cyanide wastes. Chemistry and Industry, 1232-1238. Solano-Muñoz, F. \& Bardsley, W. G. (1981). The generation of non-linear solute gradients for chromatography by using only simple apparatus. Biochenical Journal 193, 991-996.

WARE, G. C. \& PAINTER, H. A. (1955). Bacterial utilization of cyanide. Nature, London 175, 900.

WinTER, J. A. (1963). The use of a specific actinomycete to degrade cyanide wastes. In Proceedings of the 18th Industrial Waste Conference, pp. 703-716. Indiana: Purdue University. 